RICYDE. REVISTA INTERNACIONAL DE CIENCIAS DEL DEPORTE

http://www.ricyde.org

doi: $10.5232 /$ ricyde

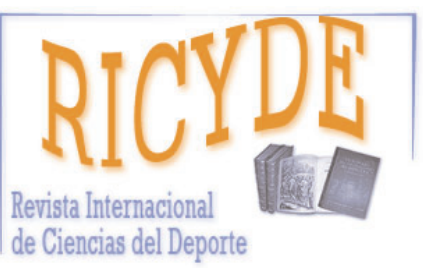

RICYDE. Revista Internacional de Ciencias del Deporte Volume XI - Year XI

Pages:192-195 ISSN : $1885-3137$

Issue 41 - July - 2015

EDITORIAL

http://dx.doi.org/10.5232/ricyde2015.041ed

\title{
The importance of intensity in the prescription of health training [La importancia de la intensidad en la prescripción de entrenamiento para la salud]
}

\author{
Vicente Javier Clemente-Suarez \\ European University of Madrid. Spain
}

\section{Introduction}

Traditionally the prescription of physical activity for health has been focused on continuous low-intensity activities. These trainings were oriented to the development or maintenance of cardiorespiratory fitness, prescribing intensities close to $50 \%$ of maximal oxygen uptake (VO2max) (ACSM, 1978). These intensity prescriptions have been criticized for their lack of specificity to obtain adaptations and for the often erroneous intensity prescribed, considering using the heart rate reserve (HRR) or reserve oxygen uptake (VO2R) as parameters to prescribe exercise intensity (ACSM, 1998; Karvonen, Kentala and Mustala, 1957). In the same way, others authors proposed the necessity to overcome the mobilization threshold to obtain adaptations, then, the prescribed intensity should be higher, proposing intensities that can reach the $85 \%$ of VO2R (ACSM, 2006; Asikainen, et al., 2002; Mors et al., 2004). Although these new intensity requirements, the exercises recommended still based on continuous methodologies, using aerobic exercises like walking, running... Currently, new training methodologies based on high intensity interval and strength exercises are showing major adaptations to different organic systems and greater efficiency than traditional training models based on continuous and low intensity training.

\section{Benefits of intensity in aerobic exercise}

New training models based on training intensity, that break with traditional approaches based on high volumes performed at low intensity, are showing greater improvements and higher training efficiency than this traditional training (Clemente-Suárez, Fernandes, ArroyoToledo, Figueredo, Gonzalez, Vilas-Boas, 2014; ArroyoToledo, Clemente-Suárez, Gonzalez, Ramos, Sortwell, 2013). Within these methodologies highlight the high intensity interval training (HIIT) that archived higher aerobic performance adaptations than traditional continuous methodologies (Gibala et al., 2006; 2012). This fact is due to the high stimulation of one of the major regulators of mitochondrial biogenesis in the muscle, the activated receptor gamma peroxisome proliferator (PGC-1 $\alpha$ ) (Little \& Cochran, 2011; Wu et al., 1999), being the essential factor to produce this stimulation of PGC-1 $\alpha$ the exercise intensity (Egan et al., 2010).
The main adaptations evaluated with this type of training compared to traditional training include increased activity of oxidative enzymes of fatty acids in muscle, increased buffering capacity, increased content of glucose transporter protein type 4 (GLUT4), increased glucose transport activity in skeletal muscle, increased citrate synthase, increased $\mathrm{VO} 2 \max$ and lactate threshold velocity (Gibala et al., 2006; Gibala et al., 2012; Terada, Tabata, \& Higuchi. 2004; Terada et al., 2001; Tabata et al., 1997; Gharbie et al., 2008; Enoksen et al., 2010).

\section{Effect of high intensity training in health}

Several authors have shown that increases in PGC$1 \alpha$ improve the oxidative capacity, antioxidant defence, glucose consumption, resistance to agerelated sarcopenia and organic anti-inflammatory pathways (Sandri et al., 2006; Benton et al., 2010; Wenz et al., 2009). The HIIT induces great magnitude increases of cellular stress and peripheral vessels, effectively isolating the heart of this stress due to the short duration of the series (Little et al., 2011), which improves endothelial function (Wisloff et al., 2007; Tjonna et al., 2013; Moholdt et al., 2009), rest blood pressure (Rognmo et al 2004; Schjerve et al 2008, Whyte et al., 2010) and left ventricular morphology (Wisloff et al., 2007).

The HIIT have shown higher efficacy than continuous training, significantly increasing the cardiorespiratory fitness by almost double than moderate intensity continuous training, being a safety training in patients with lifestyle-induced chronic diseases (Weston, Wisloff \& Coombes, 2014); archiving positively changes in blood lipids and improving insulin sensitivity compared to moderate-intensity exercise in obese adolescent females (Racil et al., 2013); inducing beneficial alterations in the resting inflammatory profile and adipose tissue proteome on overweight and obese males (Leggate et al., 1985); archiving greater and more lasting effects on reducing incremental postprandial glucose response in obese adults compared with continuous moderate-intensity training (Little, Jung, Wright, Manders, 2014); 
increasing the capacity for fat oxidation during exercise in women (Talanian, Galloway, Heigenhuaser, Bonen, Spriet, 1985); increasing the fat and carbohydrate metabolic capacities in skeletal muscle (Perry, Heigenhauser, Bonen, Spriet, 2008); and also was associated with increased patient compliance and improved cardiovascular and metabolic outcomes and weight loss (Shiraev \& Barclay, 2012).

Specifically in diabetic patients, HIIT improved both the hepatic insulin sensitivity in sedentary overweight subjects (Whyte et al, 2010; Hood et al., 2011) and the insulin sensitivity due to the improvement in peripheral GLUT4, which was increased twice after a HIIT than a low intensity and high volume training (Hood, et al., 2011). Also, HIIT improve rapidly the GLUT4 content in skeletal muscle and reducing the blood glucose concentration (Little et al., 2011). In longer training interventions the implementation of HIIT improved the glycaemic control and aerobic capacity in glucose intolerant patients (Mancilla et al, 2014) and modified the post-exercise energy intake, decreasing the fact intake in comparation to moderate interval training (Alkahtani, Byrne, Hills, King, 2014). Another important aspect about HIIT, and the PGC-1 $\alpha$ increases that produce, is the decrease in the action of transcription factor family FoxO3, whose activation is related to muscle wasting (Sandri et al., 2006). This point would be important to include in training programs for older, as proposed recent research with this population (McKean, Stockwell \& Burkett, 2012). Furthermore was found a greater negative energy balance after HIIT than after continuous exercise (Gerber et al., 2014) without an increased appetite (Deighton et al., 2013).

\section{The future of high intensity training for health}

The intensity is one of the most important key factors to increase athletes' performance, and gradually the current periodization training systems are adapting to the scientific evidences. Likewise in health area, the exercise recommendations and new training programs must be adapting the exercise prescription to models based on the intensity since they were more efficient and effective than traditional high volume low intensity training, but still needing more research to clarify a general recommendations for prescribing high intensity training in health training programs and in different populations either healthy or with some kind of pathology.

\section{References}

Alkahtani, S.A.; Byrne, N.M.; Hills, A.P.; King, N.A. (2014). Interval training intensity affects energy intake compensation in obese men. International Journal of Sport Nutrition Exercise and Metabolism, 24(6): 595-604. http://dx.doi.org/10.1123/ijsnem.2013-0032

American College of Sports Medicine (1998). Position Stand. The recommended quantity and quality of exercise for developing and maintaining cardiorespiratory and muscular fitness, and flexibility in healthy adults. Medicine \& Science in Sports \& Exercise, 30, 975-991.

http://dx.doi.org/10.1097/00005768-199806000-00032

American College of Sports Medicine (2006). ACSMs Guidelines for Exercise Testing and Prescription. 7 th Edition. Baltimore: Lippincott Williams \& Wilkins

American College of Sports Medicine. Position Stand (1978). The recommended quantity and quality of exercise for developing and maintaining fitness in healthy adults. Medicine \& Science in Sports \& Exercise, 10, vii-x.

Arroyo-Toledo, J.; Clemente-Suárez, V.; Gonzalez, J.; Ramos, D.; Sortwell, D. (2013). Comparison Between Traditional And Reverse Periodization: Swimming Performance And Specific Strength Values. International Journal of Swimming Kinetics, 2(1): 87-96.

Asikainen, T. M.; Miilunpalo, S.; Oja, P.; Rinne, M.; Pasanen, M., Uusi.Rasi, K.; Vuori, I. (2002). Randomised, controlled walking trials in postmenopausal women: the minimum dose to improve aerobic fitness?. British Jorunal of Sport Medicine, 36: 189-194.

http://dx.doi.org/10.1136/bjsm.36.3.189

Benton, C.; Holloway, G.; Han, X.; Yoshida, Y.; Snook, L.; Lally, J.; Glatz, J.; Luiken, J.; Chabowsky, A.; Bonen, A. (2010). Increased levels of peroxisome proliferator-activated receptor gamma, coactivator 1 alpha (PGC-1 $\alpha$ ) improve lipid utilisation, insulin signalling and glucose transport in skeletal muscle of lean and insulin-resistant obese Zucker rats. Diabetologia, 53, 2008-2019. http://dx.doi.org/10.1007/s00125-010-1773-1

Clemente-Suárez, V.; Fernandes, R.; Arroyo-Toledo, J.; Figueredo, P.; González, J.; Vilas-Boas, J. (2015). Autonomic adaptation after traditional and reverse swimming training periodizations. Acta Physiologica Hungarica, 102(1), 105-113.

Deighton, K.; Karra, E.; Batterham, R.L.; Stensel, D.J. (2013). Appetite, energy intake, and PYY3-36 responses to energy-matched continuous exercise and submaximal high-intensity exercise. Applied Physiological Nutrition and Metabolism, 38(9), 947-952.

http://dx.doi.org/10.1139/apnm-2012-0484 
Egan, B.; Carson, B.P.; Garcia-Roves, P.M.; Chibalin, A.V.; Sarsfield, F.M.; Barron, N.; McCaffrey, N.; Moyna, N.M.; Zierath, J.R.; O'Gorman, D.J. (2010). Exercise intensitydependent regulation of peroxisome proliferator-activated receptor coactivator- 1 mRNA abundance is associated with differential activation of upstream signalling kinases in human skeletal muscle. Journal of Physiology, 588, $1779-1790$

http://dx.doi.org/10.1113/jphysiol.2010.188011

Enoksen, E.; Shalfawi, S.; Tonnessen, E. (2011). The effects of high vs low intensity training on aerobic capacity in well trained middle distance runners. Journal of Strength and Conditioning Research, 25(3), 812-818.

http://dx.doi.org/10.1519/JSC.0b013e3181cc2291

Gerber, T.; Borg, M.L.; Hayes, A.; Stathis, C.G. (2014). High-intensity intermittent cycling increases purine loss compared with workload-matched continuous moderate intensity cycling. European Journal of Applied Physiology, 114(7), 1513-1520. http://dx.doi.org/10.1007/s00421-014-2878-x

Gharbi, A. ; Chamari, K. ; Kallel, A., Ahmaidi, S. ; Tabka, Z., \& Abdelkarim, Z. (2008). Lactate Kinetics After Intermittent and Continuous Exercise Training. Journal of Sports Science \& Medicine, 7(2), 279-285.

Gibala, M.; Little, J.P.; Van Essen, M.; Wilkin, G.P.; Burgomaster, KA.; Safdar, A.; Raha, S., \& Tarnopolsky M. (2006) Short-term sprint interval versus traditional endurance training: similar initial adaptations in human skeletal muscle and exercise performance. Journal of Physiology, 575(3), 901-911.

http://dx.doi.org/10.1113/jphysiol.2006.112094

Gibala, M.; Little, J.; MacDonald, M.; Hawley, J. (2012). Physiological adaptations to low-volume, high-intensity interval training in health and disease. Journal of Physiology, 590(Pt 5), 1077-1084.

http://dx.doi.org/10.1113/jphysiol.2011.224725

Hood, M.S.; Little, J.P.; Tarnopolsky, M.A.; Myslik, F., \& Gibala, M.J. (2011). Low-volume interval training improves muscle oxidative capacity in sedentary adults. Medicine \& Science in Sports \& Exercise, 43, 1849-1856. http://dx.doi.org/10.1249/MSS.0b013e3182199834

Karvonen, M. J.; Kentala, E., \& Mustala, O. (1957). The effects of training on heart rate: a longitudinal study. Annales Medicinae Experimentalis Et Biologiae Fenniae, $35,307-315$

http://www.ncbi.nlm.nih.gov/pubmed/13470504

Leggate, M.; Carter, W.G.; Evans, M.J.; Vennard, R.A.; Sribala-Sundaram, S.; Nimmo, M.A. (1985). Determination of inflammatory and prominent proteomic changes in plasma and adipose tissue after high-intensity intermittent training in overweight and obese males. Journal of Applied Physiology, 112(8), 1353-1360.

http://dx.doi.org/10.1152/japplphysiol.01080.2011
Little, J.P.; Jung, M.E.; Wright, A.E.; Wright, W.; Manders, R.J. (2014). Effects of high-intensity interval exercise versus continuous moderate-intensity exercise on postprandial glycemic control assessed by continuous glucose monitoring in obese adults. Applied Physiological Nutrition and Metabolism, 39(7), 835-841.

http://dx.doi.org/10.1139/apnm-2013-0512

Little, J.P., \& Cochran A. (2011). Regulating the regulators: the role of transcriptional regulatory proteins in the adaptive response to exercise in human skeletal muscle. Journal of Physiology, 589(7), 1511-1512.

http://dx.doi.org/10.1113/jphysiol.2011.205401

McKean, M.R.; Stockwell, T.B.; Burkett, B.J. (2012). Response to Constant and Interval Exercise Protocols in the Elderly. Journal of Exercise Physiology online, 15(2), 30-39.

Mancilla, R.; Torres, P.; Álvarez, C.; Schifferli, I.; Sapunar, J.; Díaz, E. (2014). High intensity interval training improves glycemic control and aerobic capacity in glucose intolerant patients. Revista Medica Chilena, 142(1), 34-39.

http://dx.doi.org/10.4067/S0034-98872014000100006

Moholdt, T.T.; Amundsen, B.H.; Rustad, L.A.; Wahba, A.; Løvø, K.T.; Gullikstad, L.R.; Bye, A.; Skogvoll, E.; Wisløff, U.; Slørdahl, S.A. (2009). Aerobic interval training versus continuous moderate exercise after coronary artery bypass surgery: a randomized study of cardiovascular effects and quality of life. American Heart Journal. $158,1031-1037$.

http://dx.doi.org/10.1016/j.ahj.2009.10.003

Morss G. M.; Jordan A. N.; Skinner J. S.; Dunn, A.L.; Church, T.S.; Earnest, C.P.; Kampert, J.B.; Jurca, R.; Blair, S.N. (2004). Dose-response to exercise in women aged 4575 yr (DREW): Design and Rationale. Medicine \& Science in Sports \& Exercise, 36, 336-344.

http://dx.doi.org/10.1249/01.MSS.0000113738.06267.E5

Perry, C.G.; Heigenhauser, G.J.; Bonen, A.; Spriet, L.L. (2008). High-intensity aerobic interval training increases fat and carbohydrate metabolic capacities in human skeletal muscle. Applied Physiology Nutrition and Metabolism, 33(6), 1112-1123.

http://dx.doi.org/10.1139/H08-097

Pintar, J. A.; Robertson, R. J.; Kriska, A. M.; Nagle, E., \& Goss, F. L. (2006). The influence of fitness and body weight on preferred exercise intensity. Medicine \& Science in Sports \& Exercise, 38, 981-988.

http://dx.doi.org/10.1249/01.mss.0000218128.66077.97

Racil, G.; Ben Ounis, O.; Hammouda, O.; Kallel, A.; Zouhal, H.; Chamari, K.; Amri, M. (2013). Effects of high vs. moderate exercise intensity during interval training on lipids and adiponectin levels in obese young females. European Journal of Applied Physiology, 13(10), 2531-40. http://dx.doi.org/10.1007/s00421-013-2689-5 
Rognmo, Ø.; Hetland, E.; Helgerud, J.; Hoff, J., \& Slørdahl, S.A. (2004). High intensity aerobic interval exercise is superior to moderate intensity exercise for increasing aerobic capacity in patients with coronary artery disease. European Journal of Cardiovascular Preventive Rehabilitation, 11, 216-222.

http://dx.doi.org/10.1097/01.hjr.0000131677.96762.0c

Sandri, M.; Lin, J.; Handschin, C.; Yang, W.; Arany, Z.P.; Lecker, S.H.; Goldberg, A.L.; Spiegelman, B.M. (2006). PGC-1alpha protects skeletal muscle from atrophy by suppressing FoxO3 action and atrophy-specific gene transcription. Proceedings of the National Academy of Sciences of the United States of America, 103(44), 16260-16265.

http://dx.doi.org/10.1073/pnas.0607795103

Sandri, M.; Lin, J.; Handschin, C.; Yang, W.; Arany, Z.P.; Lecker, S.H.; Goldberg, A.L., \& Spiegelman, B.M. (2006). PGC-1 $\alpha$ protects skeletal muscle from atrophy by suppressing FoxO3 action and atrophy-specific gene transcription. Proceedings of the National Academy of Sciences, 103, 16260-16265.

http://dx.doi.org/10.1073/pnas.0607795103

Schjerve, I.E.; Tyldum, G.A.; Tjønna, A.E.; Stølen, T.; Loennechen, J.P.; Hansen, H.E.; Haram, P.M.; Heinrich, G.; Bye, A.; Najjar, S.M.; Smith, G.L.; Slørdahl, S.A.; Kemi, O.J., \& Wisløff, U. (2008). Both aerobic endurance and strength training programmes improve cardiovascular health in obese adults. Clinical Science (London), 115, 283-293.

http://dx.doi.org/10.1042/CS20070332

Shiraev, T., Barclay, G. (2012). Evidence based exercise clinical benefits of high intensity interval training. Australian Family Physician, 41(12), 960-962. http://www.ncbi.nlm.nih.gov/pubmed/23210120

Tabata, I. ; Irisawa, K. ; Kouzaki, M. ; Nishimura, K. ; Ogita, F. ; Miyachi, M. (1997). Metabolic profile of high intensity intermittent exercises. Medicine \& Science in Sports \& Exercise, 29, 390-395. http://dx.doi.org/10.1152/japplphysiol.01098.2006

Talanian, J.L.; Galloway, S.D.; Heigenhauser, G.J.; Bonen, A.; Spriet, L.L. (1985). Two weeks of high-intensity aerobic interval training increases the capacity for fat oxidation during exercise in women. Journal of Applied Physiology, 102(4), 1439-1447.

Terada, S.; Tabatat, I., \& Higuchi, M. (2004). Effect of high-intensity intermittent swimming training on fatty acid oxidation enzyme activity in rat skeletal muscle. Japanese Journal of Physiology, 54(1), 42-52. http://dx.doi.org/10.2170/jjphysiol.54.47

Terada, S.; Yokozeki, T.; Kawanaka, K.; Ogawa, K.; Higuchi, M.; Ezaki, O., \& Tabata, I. (2001). Effects of highintensity swimming training on GLUT-4 and glucose transport activity in rat skeletal muscle. Journal of Applied Physiology, 90, 2019-2024.

http://www.ncbi.nlm.nih.gov/pubmed/11356760
Terada, S.; Yokozeki, T.; Kawanaka, K.; Ogawa, K.; Higuchi, M.; Ezaki, O., \& Tabata, I. (2001). Effects of high-intensity swimming training on GLUT-4 and glucose transport activity in rat skeletal muscle. Journal of Applied Physiology, 90, 2019-2024.

http://www.ncbi.nlm.nih.gov/pubmed/11356760

Tjonna, A.; Leinan, I.; Bartnes A.; Jonssen, B.; Gibala, M.; Winett, R.; Wisloff, U. (2013). Low- and High-Volume of Intensive Endurance Training Significantly Improves Maximal Oxygen Uptake after 10-Weeks of Training in Healthy Men. PLOSONE, 8(5), pp?

http://dx.doi.org/10.1371/journal.pone.0065382

Wenz, T.; Rossi, S.; Rotundo, R.; Spiegelman, B.; Moraes, C. (2009). Increased muscle PGC-1 $\alpha$ expression protects from sarcopenia and metabolic disease during aging. Biological Sciences - Medical Sciences, 106 (48), 2040520410.

Weston, K.S.; Wisløff, U.; Coombes, J.S. ( 2014). Highintensity interval training in patients with lifestyle-induced cardiometabolic disease: a systematic review and metaanalysis. British Journal of Sport Medicine, 48(16), $1227-$ 12234.

http://dx.doi.org/10.1136/bjsports-2013-092576

Whyte, L.J.; Gill, J.M., \& Cathcart, A.J. (2010). Effect of 2 weeks of sprint interval training on health-related outcomes in sedentary overweight/obese men. Metabolism, 59, $1421-1428$.

http://dx.doi.org/10.1016/j.metabol.2010.01.002

Wilmore, J. H., y Costill. D. (2004). Fisiología del esfuerzo y del deporte. 5Ed. Paidotribo. Barcelona.

Wisløff, U.; Ellingsen, Ø., \& Kemi, O.J. (2009). Highintensity interval training to maximize cardiac benefits of exercise training? Exercise Sport Science Review, 37, 139-146.

http://dx.doi.org/10.1097/JES.0b013e3181aa65fc

Wisløff, U.; Støylen, A.; Loennechen, J.P.; Bruvold, M.; Rognmo, Ø.; Haram, P.M.; Tjønna, A.E.; Helgerud, J.; Slørdahl, S.A., Lee, S.J.; Videm, V.; Bye, A.; Smith, G.L.; Najjar, S.M.; Ellingsen, Ø.; Skjaerpe, T. (2007). Superior cardiovascular effect of aerobic interval training versus moderate continuous training in heart failure patients: a randomized study. Circulation, 115(24), 3086-3094. http://dx.doi.org/10.1161/CIRCULATIONAHA.106.675041

Wu, Z.; Puigserver, P.; Andersson, U.; Zhang, C.; Adelmant, G.; Mootha, V.; Troy, A.; Cinti, S.; Lowell, B.; Scarpulla, R.C.; Spiegelman, B.M. (1999). Mechanisms controlling mitochondrial biogenesis and respiration through the thermogenic coactivator PGC-1. Cell, 98(1), $115-124$.

http://dx.doi.org/10.1016/S0092-8674(00)80611-X 